Невена Јанићијевић

Факултет за културу и медије

Универзитет Мегатренд

Београд

nevenajm@yahoo.com

https://doi.org/10.18485/ai_san_o_gradu.2019.ch12

821.134(7/8).09 Кортасар X.

\title{
ПАРИЗ И БУЕНОС АЈРЕС, ДВА МИТСКА ГРАДА АРГЕНТИНСКОГ ПИСЦА ХУЛИЈА КОРТАСАРА
}

Хулио Кортасар у свом роману Школице, као и у богатој преписци пријатељима из Аргентине као танку нит провлачи два града, Париз у Европи и Буенос Ајрес у Латинској Америци. Париз је наставак трагања, његов 'пут за Дамаск', који у себи носи питања ко смо, одакле смо, где идемо, а Буенос Ајрес представља оно суштинско, укорењено у самом Кортасару, чега није ни свестан док не напусти родни град, са непуних четрдесет година. Одласци и доласци, померање у простору и времену, спајају невидљивим нитима ова два града као неки необичан сан никад до краја одсањан. Ликови у његовом роману, а и његов стварни живот у Паризу, испреплетани су у једну непрегледну реку непознатих, а некада и врло препознатљивих квартова Париза и Буенос Ајреса.

Кључне речи: Париз, Буенос Ајрес, Кортасар, Школище.

Као и многи интелектуалци његовог времена Кортасар је писац који је живео између два света, Европе и Америке.

Године 1951. добија стипендију и одлази у Париз на годину дана, али остаје у њему читавог живота. Као што сам каже, он не одлази из земље због политичких 
прилика, већ из жеље да види Париз, град која за писце Латинске Америке представља центар света, 'кибуц жеље'. Ипак он не престаје да буде аргентински писац и пише на шпанском. Иако настањен у Паризу, његов поглед је увек упрт ка Буенос Ајресу.

Кортасар ствара у новом окружењу. Он је одушевљен Паризом, сваки дан иде у Лувр и посматра ремек-дела ликовне уметности. Посећује концерте и сусреће се са многобројним писцима. Кортасар је иначе рођен у Белгији па је француски говорио од малих ногу и имао дубок додир са културом и духовним вредностима Француске. У њему постоје један врло француски и други дубоко аргентински Кортасар. Тема двојника је код њега постављена већ на том нивоу. Касније ће двојник бити обавезна тема у причама и романима. Те почетне године у Паризу су године 'катализатори'. Сам Кортасар каже: „тада је дошло до некакве коагулације мог претходног искуства у Аргентини. Одједном за кратко време згуснула се и садашњост и прошлост, прошлост се укратко углавила у садашњост и резултат је био мучан осећај који је затим од мене тражио да напишем Школице“ (Кортасар 2012: 546).

Доласком у Француску, у Европу, судара се са другим концептима вредности. То су нови изазови који стварају другачијег Кортасара, али оног истог који већ у Буенос Ајресу зна да је хиспаноамеричке писце Борхес научио неумољивости према себи да се не објављује ништа што није књижевно веома 'коректно'. Кортасар се налази између Буенос Ајреса и Париза, између метафизике и патафизике.

Тако ће он у обимној преписци пријатељима из Аргентине до детаља описивати свакодневни живот у Паризу.

Одушевљење не јењава ни када му у посету дођу Аргентинци који гледају само испред себе, не видећи оно скривено у баштама и тајним пролазима. 
Примећујем да када дођу Аргентинци, они ходају улицама гледајући само испред себе, као у Буенос Ајресу. Ни горе ни са стране. Тако губе (из вида) сва невероватна предворја, тајанствене улазе са старим вртовима, са фонтанама и статуама, дворишта од пре три века, нетакнута. ${ }^{1}$ (Кортасар 2010: 139)

У децембру 1952. долази Аурора Бернандес, његова будућа супруга. Париз је чаробан град са доковима на Сени, позориштима, музиком, биоскопима. То је град лепоте, град где може да слуша уживо Луиса Армстронга, музичара кога је волео од ране младости. У Паризу сусреће 'богове из своје младости'.

Са доласком Ауроре, Кортасар се већ осећа као староседелац који пријатељима показује лепоте града, од мале улице Муфтар која је препуна продавница хране до дивних квартова као што је Маре. Са Аурором живот у Паризу тече својим током, сваки дан има неку своју рутину, посао, шетње. Посете кафеима, позориштима и музејима су обавезне, а једноставни оброци код куће одају утисак да је њихов заједнички живот скроман, пун културних дешавања, свега онога што није могло да види и осети у Буенос Ајресу. Њихов живот је врло једноставан, али чаробан за млади брачни пар који упија све лепоте овога града:

Препуштамо се Паризу, улазимо у неку кафетерију да нешто попијемо, купујемо необичне бисквите, проверавамо цене хотела и пансиона, само јер нам се свиђа да мислимо како би било лепо живети у улици Бак, или

1 "Observo que los argentinos que llegan, andan por las calles mirando solo de frente, como en B.A. Ni hacia arriba ni a los costados. Se pierden todos los increíbles zaguanes, las entradas misteriosas que dan a jardines viejos, con fuentes o estatuas, los patios de hace tres siglos, intactos..." 
Сен, или на тргу Фурстенберг. Гледамо долазак поподнева, а да не знамо колико је сати; ако је сиво у Лувру смо, или у некој цркви или истражујемо Маре. ${ }^{2}$ (Кортасар 2010: 146)

Кортасар је доживео промену у Паризу, не само на књижевном плану. Он сам каже да је искуство које је тамо проживео није могло да се пореди са усамљеним животом који је водио у Аргентини „Париз је био мој пут за Дамаск, нагли егзистецијализам..." (Бермехо 2013: 12), који га је упутио ка свом ближњем. Те педесете године за њега су биле кључне, 'збијеност садашњости и прошлости', где су све вредности које је стекао у Аргентини у Француској биле доведене у питање. То искуство је за њега било добро, иако никад није престао да пише на шпанском језику. Такође спомиње да није отишао из Аргентине могао би да постане добар приповедач, само тамо никада не би написао дело као што су Школище.

Школище излазе из штампе 1963. када је он већ десет година у Паризу. Сва искуства, осећања, патње, бол и радости су се слили у ову књигу. Он ју је писао полако, на разним комадима папира, салвета, где год би стигао и онда је одлучио да све то скупи у једну књигу. У књигу која на површини нема ни почетак ни крај, чија се поглавља циклично настављају, јер када стигнете до краја првог дела књиге писац вас упућује да сада књигу још једном прочитате али на прескоке, уклапајући поглавља из другог дела књиге са првим и све то, наравно, ако желите.

2 „Derivamos, entonces, por Paris, entrando en algún café a beber algo, comprando raros bizcochos, averiguando precios de hoteles y pensiones por el solo gusto de pensar que bonito seria vivir en la rue du bac o en la rue de Seine o en la place Furstenberg. Vemos venir la tarde, sin conciencia de tiempo; si hace gris nos metemos en Louvre, o en una iglesia, o exploramos Marais.“ 
Љиљана Павловић Самуровић у свом Лексикону хиспаноамеричке кюижевности сматра да овај роман представља револуцију у књижевности, јер је Кортасар по мишљењу многих аутора хтео да разбије класичну форму романа и дело приближи реду хаоса који по његовом уверењу влада на земљи. Аутор је применио нетипичан наративан поступак, неконвенционалну структуру. Роман се састоји из два дела; први део је назван 'са ове и са оне стране', а други 'са других страна', где у облику колажа износи своје ставове о књижевности, о свакодневном животу, политици. Уводи читаоца саучесника и упутство за употребу: да се роман чита следећи бројеве као када се играју школице. Опонашајући школице писац прави структуру дела и сама игра постаје човеково трагање за небом. Баца се камичак, али небо увек некако измиче, односно кад дођемо до неба ми смо одрасли и тражимо неко друго небо.

Друго небо може бити из перспективе писца у егзилу и град из кога је отишао, Буенос Ајрес. Ту се мора имати на уму да је Кортасар егзил почео другачије. Он је напустио Аргентину 1951. године својом вољом и без политичких притисака, али се тек од 1974. почео осећати као у егзилу. Међутим ту се ради и о културном егзилу, који је више 'болан' него онај физички. Године 1974. Војна хунта му забрањује издање нових прича, то јест књига се може штампати ако се из садржаја избаце две приповетке („Апокалипса у Солентинамену“ и „Други пут“). Прва осликава деструкцију друштва у Никарагви на острву Солентинамену, а друга се бави на индиректан начин бројним нестанцима у Аргентини. Није се осећао изгнаником до тренутка кад су му забранили штампање књиге, што би наравно значило да би могао да уђе у Аргентину, али сигурно не би могао из ње да изађе. 
За Кортасара као Латиноамериканца Париз је сан, који је од њега направио човека, писца. Париз је за њега жена, 'жена мог живота'. Он се понекад пита и зашто је 'ког ђавола написао ову књигу' која је за њега нека врста 'егзорцизма' како каже у интервјуу Бермеху, јер да је није написао сигурно би се бацио у Сену. Овај роман за њега је била 'атомска бомба' бачена на хиспаноамеричку књижевност у намери да је продрма, освести и да нешто ново, до тад невиђено.

Кортасар Школице почиње питањем „Хоћу ли наћи Магу?“" (Кортасар 1993: 11). Главни јунак Орасио Оливеира је човек настањен у Паризу који стално тражи ствари, људе, идеје. Он то зове 'кибуцом жеље' или 'центром', како нам сам писац то каже у разговору са Омар Прего Гадеом (објављеном под називом „Одушевљење речима"). Наравно, те теме су биле врло блиске младим људима па зато и ова књига највећи успех управо дугује њима. Млад човек је тај који све доводи у питање, који негира традиционалне дубоко укорењене норме и правила да би пронашао свој пут.

У роману Оливеира упознаје град заједно са Магом, њен поглед на свет га мења јер та необична жена поштује своја правила како у емотивним односима тако и у обичном свакодневном животу. Они живе свој живот кроз неку игру, где и састанак постаје једно ново искуство.

Природно је тада било да пређем улицу, да се попнем уз степенице моста, да крочим у његове издужене облике и да приђем Маги која би се на то осмехнула без изненађења, уверена као и ја да случајни сусрет представља нешто понајмање случајно у нашим животима а да састанке уговарају они људи који се дописују на хартији са линијама или зубну пасту истискују одоздо. (Кортасар 1993: 11) 
Њихов заједнички живот се преплиће са пријатељима, изласцима, слушањем музике и разговорима о уметности. Оливеира је често посматрач, он слуша и упија све нове тренутке које му даје живот у Паризу, а критичари сматрају да је управо он двојник самог писца, који је кроз њега износио своје ставове о животу. Скромни почеци Кортасаровог становања у Паризу понајбоље су описани у роману у становима без грејања или купатила, али где је могла да се слуша гласно музика. Стварност и фикција су код њега врло повезани, па чини да је Кортасар у Школицама дао слику свог живота у Паризу, описујући скривене кутке тог града, доступне само онима који желе да виде нешто друго сем бљештавила широких булевара. Тај други Париз кога је Кортасар врло волео је био у складу са Кортасаром из тог времена, првих година у Паризу, када је живео од позајмица, шетао улицама града и био срећан само што је ту где јесте, у Паризу. Тај скривени град испод града се види и у следећем одломку:

Тако се беху препустили једном нестварном Паризу вођени знаковима ноћи, путањама никлим из речи каквог клошара, из осветљеног поткровља на крају улице, а застајкивали би на малим трговима створеним да се људи исповедају, да се љубе на клупама или да гледају школице, онај дечији обред са кредом и скакањем на једној нози да би се стигло на Небо. (Кортасар 1993: 30)

Између Монпарнаса и Лез Ал Оливеира и Мага играју своју игру налажења циља, без претходног договора. Лида Арон Аместој у својој књизи Кортасар роман мандала сматра да се 'Истина и Абсолут' налазе изван доброг и лошег са ове стране, то јесте са оне стране, где једно 'да' не повлачи са собом 'не'. Живот y 'апсолуту, у једном, у вечности' је ту поред, само се 
не уклапа. Да би се уклопило човек мора поново да се роди, да изникне из пепела и постане 'нови човек'. Аместој сумња да се може постићи тај 'нови човек' јер Кортасар и његов двојник Оливеира не знају шта траже, није им дато и зато се губе у негацији у ништавилу. Једини излаз може бити сусрет са 'ближњим' у неком новом љубавном односу. Зато је Оливеира изабрао Париз као место сусрета два бића, где се шетајући Булеваром Сен-Жермен, или на мосту Пон Неф, налази са Магом, онако на први поглед случајно: „Шетали смо, а да се нисмо тражили, али смо знали да ћемо се наћи“ (1993: 201).

Своју потрагу за 'центром' то јест смислом Оливера покушава да нађе управо на улицама Париза, док бесциљно лута. То ће покушати да објасни кроз пример играња школица.

Горе је Небо, доле је Земља, веома је тешко стићи камичком у Небо, скоро увек се погрешно израчуна па камен изађе из цртежа. Мало по мало, међутим стиче се потребна вештина у прескакању разних подеока, ... па се једног дана научи како да се изађе из Земље и да се камичак успење до Неба ... невоља је у томе што баш тада, када готово нико други није научио да доведе камичак до Неба, детињству изненада долази крај и човек запада у романе, у неподношљиву тескобу, у спекулисање о другом небу до којег такође треба научити да се стигне. И због тога што је изашао из детињства ... човек заборавља да су му за стизање у Небо потребни, као опрема, један камичак и врх ципеле. (Кортасар 1993: 228)

Тако Кортасар главног јунака смешта у један замишљен град, готово митски. Он се налази баш у Паризу и путовање кроз његове квартове и улице му даје сваки пут други одговор на питање о смислу живота и да ли је то прави пут којим иде. И колико има тих 
правих путева и да ли ће доћи до свог 'кибуца жеље'. Симболе које користи Кортасар да би дао смисао свом егзистенцијалном питању ко је он у ствари су обичне ствари: дечија игра, камичак и врх ципеле. Он зна да је то довољно, али му то коначно решење ипак измиче, јер када дође на крају до Неба, тог жељеног циља, он више није дете, већ одрастао човек, коме сада требају врата за нека друга Неба.

У последњем поглављу првог дела Орасио констатује да је:

...небо у истој равни са земљом на прљавом плочнику игре, а једног дана ће човек можда ступити у свет где изговорити Небо не би више била нека умашћена крпа, и једног дана ће можда угледати право лице света, patterns pretty as can be, а можда ће, гурајући камен, на крају ући у кибуц. (Кортасар 1993: 230)

Кортасар на тај начин оставља отвореним све путеве који воде до жељеног циља, до сањаног града, а главни јунак није сигуран у исход свог путовања. Недостижни циљ можда је само умашћена крпа, а можда и није, само то и није важно, јер свеукупна слика света измиче којим год путем да се крене.

Кортасар као писац и као човек нашао је своје 'Небо', управо над Паризом, јер је читав живот провео у њему, али његов јунак из Школица као да нема довољно могућности или доказа да то уради. Наравно мора се имати у виду да је Кортасар износио своје критичке ставове о књижевности, егзистенцијализму, управо кроз Оливеиру, али и да је у исто време и био његов опонент. Јер више од свега Кортасар је волео да се игра, сматрао је да је игра важан облик мишљења и делања и да кроз игру, хумор и иронију може лакше да се разуме свет у коме живимо. 
Он се поигравао са стварношћу и фикцијом, тј. његово сударање стварности са фикцијом, како Грасијела Матуро наводи „тај свет мрачних предела духа или митских форми“" у судару са стварним, управо су један рационалан приступ којем теже писци. Она даље наводи да је Кортасар овим делом управо појачао митско-поетски пут као начин везе са стварношћу, превазилазећи временско-просторне категорије. Такође је променио пут мишљења, употребу аналогије у књижевном делу, где је књига представљена као анти-роман, без хронолошко-просторног континуума. И на крају на етичко-моралном плану, стављање теме љубави као јединство форме и садржаја и као освешћење самог бића у његовој потрази за 'центром'. Негација својег 'ја' и предавање другоме су само елементи којима Кортасар жели да дође до одговора. Премда он на једној страни понавља реченицу „У дубини, знао сам да се не може ићи даље, јер даље не постоји“, он ту реченицу понавља неколико пута дуж читаве странице, тако да се поставља питање да ли је Оливеира успео да дође до свог кибуца. То је отворено питање, јер до краја књиге остаје нејасно шта се догодило са главним јунаком, да ли је отишао у ништавило (као што је већина критичара сматра ) или је наставио свој живот у Буенос Ајресу.

У Буенос Ајрес, главни јунак се враћа у роману на необичан начин, како сам каже 'јер Оливеира није имао где да оде'. Када је завршио прескакање школица у Паризу (од љубави према Маги, до слушања џеза и сусрета са клошарима), он се настањује у Буенос Ајресу, а нека друга музика и неке друге љубави се провлаче кроз његов живот. Док у Паризу има француске пријатеље, у родном граду се дружи са Аргентинцима. То је нов језик, ново окружење, а по речима Грасијеле Матуро он и даље остаје посматрач, који игра нове игре. Тра- 
велер, Оливеирин пријатељ из младости, пита се да ли се Оливеира заиста вратио у Буенос Ајрес, да ли се помирио са родним градом, док шетају по улицама града, слушају Гардела, или једу цревца и роштиљ у оближњој кафаници. Оливеира опет мисли да никада није ни отишао из града, да је све исто као и пре, врућина, пијење матеа, разговори о музици, о књижевности. Он критикује Буенос Ајрес, али то ради из чисте љубави према њему и не може'лицемерно да се помири са њим, јер је сад много даље од своје земље, него кад је био у Европи' (Кортасар, од А до 3, 2014 : 53). Оливеира воли да живи живот правог Портењца, где време споро тече, и пије се мате чај поподне, онда се шета по великим булеварима или уским лицама Сан Телма, тражећи спас од подневне жеге.

Оливеирин двојник Кортасар је живео у преграђу Буенос Аjpeca, у четврти Банфилд са мајком и сестром до 1934. Касније се преместио у кварт Роусон ван града, где су пусте улице и миран живот доприносиле томе да се Кортасар осећа још усамљенијим. Међутим, утицај родног града осећа се код њега и код Оливеире понајвише у Паризу, када говори као прави портењо (становник Буенос Ајреса), користи сленг-лунфардо, или заменицу 'вос' када каже 'ти'. Постоји носталгија за овим градом, за Аргентином, која је живела и преживела војну хунту, те он не жели више да стално буде настањен тамо, већ да је посећује.

Он излази у барове у центру града где са пријатељима слуша џез, упознаје музичаре и покушава и сам да свира трубу, иако неуспешно. Воли да посећује галерију Гуемес, данас мали тржни центар у главној пешачкој улици Флориди.

Кортасар је изгнаник из своје земље, али носталгија за њом не јењава током година и деценија живота у Европи. Како аргентијски песник Техада Гомес у песми 
„Једноставне ствари“ каже „Човек се увек враћа на стара места, где је волео живот“.

А Кортасар који је писао и песме уз пуно љубави и сете посвећује Буенос Ајресу, Аргентини, ове стихове:

Волим те земљо, прљава марамицо, са твојим улицама прекривеним постерима Перона, волим те без наде и без извињења, без враћања и без права, ништа више него из далека и огорчен у ноћи. (Амикола 1969: 194)

На крају може се закључити да је Кортасар био распет између своје две љубави, Европе и Латинске Америке, и једну и другу је волео и сањао. Буенос Ајрес и Париз, ти никад до краја одсањани градови, никад до краја проживљени и вољени, су само две тачке у простору које се међусобно преплићу у сталној потрази за смислом, центром, кибуцом жеље, где се у основи крије потреба за приближавањем ближњем, за другим, за љубављу како би се достигло Небо и било у хармонији са собом и са светом.

\section{Извори и литература}

Amicola, Jose. Sobre Cortazar. Buenos Aires: Edit. Escuela, 1969. Amestoy, Aronne Lida. Cortazar la Novela Mandala. Buenos Aires: Fernando Garcia Cambeiro, 1972

Gonzales Bermejo, Ernesto. Revelaciones de un cronopio,

Conversaciones con Julio Cortazar. Buenos Aires: El cuenco de plata, 2013.

Cortázar, Julio. Las Cartas, I -V tomo. Buenos Aires: Alfaguara, 2010- 2012.

Cortázar, Julio. Álbum Cortázar de la A a la Z, un álbum biográfico. Buenos Aires: Alfaguara, 2014.

Cortazar, Julio и Prego, Gadea Omar. La fascinación de las palabras. Buenos Aires: Alfaguara, 1997. 
Кортасар, Хулио. Школище. Београд: Bata, North American, Orbis, 1993.

Кортасар, Хулио. Сабране приче. Београд: Службени гласник, 2012

Павловић-Самуровић, Љиљана. Лексикон хиспаноамеричке книжевности. Београд: Савремена администрација, 1993.

Nevena Janićijević

\section{PARIS AND BUENOS AIRES, TWO MYTHICAL CITIES OF ARGENTINE WRITER JULIO CORTÁZAR}

Julio Cortázar, in his novel Hopscotch, as in rich correspondence with friends from Argentina, as a thin thread, he mentions two cities, Paris in Europe and Buenos Aires in Latin America. Paris is a continuation of the search, its 'journey to Damascus', which carries with it questions of who we are, where we are from, where we are going, and Buenos Aires represents that essential, rooted in Cortázar itself, which he is not even aware of until he leaves his hometown, from his less than forty years old. Departures and arrivals, a shift in space and time, connect the invisible threads of these two cities, like some strange dream never fully dreamed up. The characters in his novel, as well as his real life in Paris, are intertwined in an endless river of unknown and sometimes very recognizable neighborhoods of Paris and Buenos Aires. 